\title{
Assuring Equal Access of Asian Americans to Highly Selective Universities
}

\section{Grace W. Tsuang}

In the post-Bakke era, many institutions of higher education have sought to maintain their commitment to minority admissions programs without the use of explicit racial quotas. In Bakke, Justice Powell deemed the Harvard Admissions Program, which considers race or ethnic background a "plus" in evaluating the applicant, the ideal means to achieve ethnic diversity. ${ }^{2}$ Recently, critics have alleged that a new type of "quota, established under the auspices of diversity, sets an upper limit on the number of Asian Americans ${ }^{3}$ admitted to highly selective institutions.

This Note discusses the legal basis for a claim by an Asian American applicant denied admission to a public or private university due to an upper limit quota. An Asian applicant would not challenge the legality of preferential admissions nor allege that a Black or Hispanic had gained entrance in place of a better qualified Asian. Instead, the basis of the claim and, thus, the bulk of the data presented here, would focus on the treatment of Asian Americans compared with Caucasians, a group never intended to be the beneficiaries of affirmative action. An Asian applicant would not seek special consideration because of her race, but equitable treatment regardless of her race.

The statistics presented in Section I provide an overview of the Asian

1. In Regents of Univ. of Cal. v. Bakke, 438 U.S. 265 (1978), a Caucasian applicant to the University of California (U.C.) at Davis Medical School claimed that the special admissions program, which reserved 16 places in a class of 100 for minorities, violated his rights under the equal protection clause of the Fourteenth Amendment and Title VI of the Civil Rights Act of 1964. In a complicated plurality opinion, Justice Powell, with Justices Stevens, Burger, Stewart, and Rehnquist concurring in the judgment in part, held that the racial classifications used in the admissions program failed the "strict scrutiny" test and violated the equal protection clause. Id. at 305, 320. However, Justice Powell, with Justices Brennan, White, Marshall, and Blackmun concurring in the judgment in part, next held that race can still be considered a factor in admissions decisions. Id. at 320 .

2. Justice Powell, however, was the sole member of the Court to justify preferential admissions on the basis of "diversity." Id. at 315-19 (Powell, J.).

3. Since the term "Asian Americans" encompasses individuals from a variety of cultural, historic, and cthnic backgrounds, it raises the definitional problem of who should be included in the group, and whether "Asian Americans" should be viewed as a group at all. While these are important issues, most universities, with the exception of the U.C. system, collect data only on "Asian Americans" and/ or "Oriental Aınericans," and thus, treat Asians as a single group. For the purposes of this Note, "Asian Americans" or "Asians" refers to Americans of Chinese, Japanese, Korean, Filipino, Taiwanese, Vietnamese, Cambodian, Laotian, Asian Indian, Pacific Islander, and Thai descent. 
admissions problem as exemplified by four universities and outline the type of evidence plaintiffs should seek during discovery to challenge a university's admissions practices. Section II analyzes available legal theories and sets forth the type of allegations that should be included in a complaint against any institution. Finally, Section III offers suggestions for fashioning a remedy that would enhance the fairness of admissions practices and reduce the obstacles faced by Asians seeking entrance to the nation's highly selective universities.

\section{Evidence of Quotas on Asian American Admissions}

This Section focuses on the admissions criteria used at the University of California at Berkeley (Berkeley), Stanford, Harvard, and Brown Universities, ${ }^{4}$ and considers possible explanations for the lower numbers of Asian Americans admitted.

\section{A. The Evolution of Upper Limit Quotas on Asian Americans}

In the early 1970's, major universities adopted affirmative action programs for minority admissions which included Asian Americans within their guidelines. ${ }^{5}$ The number of Asian American students increased gradually until the 1980's, when the size of the Asian applicant pool escalated dramatically as a result of liberalized immigration policies ${ }^{\mathbf{b}}$ and an overall rise in the number of potentially qualified Asian applicants. ${ }^{7}$ At present,

4. Berkeley receives a high number of applications from Asians because of the increasing number of Asian residents in its vicinity. See Bureau of the Census, 1980 Census of Population vol. 1, - ch. D, pt. 6, at 7; vol. 1, ch. B, pt. 6, at 26 (estimating that Asians comprise $6 \%$ of the total population of California and $22 \%$ of the population of San Francisco). Stanford is an appropriate subject for study because it is also located in California, and it has analyzed its admissions process. Cited by Justice Powell as an "illuminating example," Bakke, 438 U.S. at 316, Harvard's current practices should be scrutinized. Finally, in response to student allegations of a quota on Asians, Brown has examined and produced a report on its internal admissions process. Similar claims of discrimination have also been raised at Princeton, Yale, and UCLA. See Nakanishi, Asian Pacific Americans and Selective Undergraduate Admissions, J.C. ADmissions, Winter 1988, at 18 (discussing Princeton, Yale, and UCLA). Since the complete admissions records of private institutions are not available to the general public, the statistics presented in this Note are limited and do not necessarily examine the same set of Asian and Caucasian candidates at each institution. But a plaintiff should seek to expand the data presented here through the discovery process.

5. E.g., U.C. Davis Medical School included Asians within its student affirmative action programs. Bakke, 438 U.S. at 274 (Powell, J.).

6. Hune, U.S. Immigration Policy and Asian Americans: Aspects and Consequences, in U.S. Commission on Givil Rights, Civil. Rights Issues of Asian and Pacific Americans: Myths and Realities 283-86 (1979); See also U.S. Dept. of Justice, 1986 STatistical Yearbook of The Immigration and Naturalization Service Table 2 (1987) (153,000 Asian immigrants entered the U.S. from 1951-60, compared to 428,000 from 1961-70 and 1,588,000 from 1971-80).

7. The explosion in the number of Asian SAT test-takers, an exam required at all four universities discussed in this Note, illustrates the changing demographic composition of the applicant pool. From 1978 to 1988, the number of Asian SAT test-takers increased $177 \%$ (from 23,152 to 64,102), compared to $10 \%$ for Caurasians (from 742,154 to 813,116 ). College Board, National. Report: College-Bound Seniors, 1978, at 15; College Board, Collfge-Bound Seniors: 1988 ProFILE OF SAT AND ACHIEVEMENT TEST TAKERS 6. 
Berkeley and Stanford do not consider Asians a protected minority, ${ }^{8}$ Brown does not address their status in the admissions process, ${ }^{9}$ and Harvard gives "positive weight" to Asian applicants. ${ }^{10}$

Admissions programs at many institutions granted preferences to racial minorities in the selection process, ${ }^{11}$ which frequently resulted in high admit rates ${ }^{12}$ for minority groups compared to Caucasians. Statistics from the Brown Admissions Office reflected such patterns. ${ }^{13}$ Beginning with the Class of 1985, however, Asian Americans were admitted at a lower rate than Caucasians, and the disparity continued until the Class of 1987, when only $14 \%$ of Asian applicants, compared to $19 \%$ of Caucasian applicants, were accepted for admissions. Although the number of Asian applicants continued to escalate, the number of Asian candidates accepted remained fairly constant, ${ }^{14}$ suggesting the existence of an upper limit quota. Similar disparities in admit rates occurred at Harvard ${ }^{\mathbf{1 5}}$ and Stanford, ${ }^{16}$ suggesting a trend at the nation's highly selective institutions.

8. Berkeley excludes from its "protected programs" all Asians, as defined in supra note 3, except for Filipinos. Report by the Auditor General of Galifornia, A Review of First-Year Admissions of Asians and Caucasians at THE University of California at Berkeley 5 (Oct. 1987) [hereinafter AUdITOR GenERAL's REPORT]. Stanford's catalogue states: "Given our goal of achieving a richly diverse student population, we do make special efforts to attract, [and] admit . . . students who are Black, Mexican American, and American Indian." STANFord UNIversity, STANFORD TODAY 1988-89, at v (1988) [hereinafter STanford Today].

9. Brown, however, lists Asians in its compilation of minority admissions. BROWN UNIVERSITY, REPORT TO Schools 5 (Sept. 1987).

10. In a confidential document, Harvard's Dean of Admissions stated, "The Admissions Committee gives positive weight to . . . Asian-Americans because of [their] particular . . . ethnic and cultural experiences . . . " Harvard Universtry, Asian-AMERICANS at HaRvard: Beyond RePresenTATION 4 (Nov. 1987) [hereinafter HARVARD REPORT] (unpublished draft report) (on file with author).

11. Preferential admissions was sanctioned by five Justices in Bakke. See supra notes 1-2.

12. The admit rate is the number of students admitted as a percentage of the total number of applicants in that category.

13. E.g., admit rates for Class of 1982 were $47 \%$ for Asians, $26 \%$ for Caucasians; $26 \%$ Asian versus 23\% Caucasians for Class of 1983; and 23\% Asian versus 20\% Caucasian for Class of 1984. Brown Corp. Comm. on Minority Affairs, Statistical Summary by Third World CategORIES for Classes '79-'87 (June 3, 1983), reprinted in AsIan AMERICAN Students Association (AASA), Asian American Admission at Brown University Tables 2a, 2b (Oct. 11, 1983) [hereinafter AASA REPORT].

14. From Class of 1982 to Class of 1990 , the number of Asian applicants grew from 307 to 1627, a $430 \%$ increase, while the number of Asians admitted to Brown rose from 141 to 245 , a $74 \%$ increase. Brown University, Undergraduate Admissions 29 (1987). Asian admit rates from Class of 1985 to Class of 1991 were $19 \%, 19 \%, 15 \%, 19 \%, 17 \%, 16 \%$, and $20 \%$. Id.

15. From Class of 1982 to Class of 1991 , the Asian admit rates at Harvard were $12 \%, 15 \%, 15 \%$, $14 \%, 13 \%, 14 \%, 13 \%, 12 \%, 11 \%$, and $12 \%$. In contrast, the Caucasian rates were $17 \%, 16 \%, 15 \%$, $16 \%, 18 \%, 19 \%, 18 \%, 17 \%, 18 \%$, and $16 \%$, an average of four percentage points higher than the Asian rates. Harvard Report, supra note 10, at Table 4. See infra note 71.

16. Between 1982 and 1985, "Asian-American applicants to Stanford had admission rates ranging between 66 percent and 70 percent of admission rates for whites." STANFORD UNIVERSITY, 1985-86 Annual Report of THE Committee on Undergraduate Admissions and Financial Aids 5 (1986), reprinted in The Stanford University Campus Report, Nov. 12, 1986, at 14, col. 2 [hereinafter CUAFA RFPORT]. 


\section{B. Academic Qualifications and Asian Admit Rates}

One possible explanation for the disparity between Asian and Caucasian admit rates is that Asian applicants are less academically qualified than Caucasian candidates. At Berkeley, the Auditor General of Galifornia found that from 1981 to 1987 , Caucasians gained admission to Berkeley's five colleges at rates generally higher than those of Asians, ${ }^{17}$ even though Asian applicants overall had higher grade point averages and standardized test scores. While each of Berkeley's five colleges has its own admissions formula, applicants to each college are evaluated according to a two-tiered system adopted in $1985 .^{18}$ Students in the first tier are admitted solely on the basis of scholastic criteria (grade point average, SAT scores, and three achievement tests), while students in the second tier are evaluated both on scholastic and non-academic criteria (supplemental criteria) or are admitted through various "protected programs." 18 From 1985 to 1987, the Auditor General found that for the College of Letters and Science, which accounts for seventy-eight percent of the student body, ${ }^{20}$ "the Tier 1 admission rates of Asians were higher than the admission rates of Caucasians" in all three years, while "the Tier 2 admission rates of Caucasians were higher than the Tier 2 admission rates of Asians in all three years." 21 This finding suggests that Asian applicants perform better than Caucasians on strictly academic criteria ${ }^{22}$ and implies that the use of Tier 2 methodology has a detrimental impact on Asians.

A confidential Harvard report of applicants from the Class of 1982 to Class of 1990 similarly undercuts the scholastic qualifications argument. Harvard's Admissions Office predicted that an average of $30 \%$ of Asian applicants compared to $24 \%$ of Caucasian applicants would graduate with high honors from Harvard and concluded that Asian candidates were stronger academically. ${ }^{23}$ While Harvard, Brown, and Stanford do not claim that they admit applicants exclusively on the basis of scholastic ability, academic qualifications presumably play a significant role in the selec-

17. Alidtor General's Report, supta note 8, at P-722, S-4.

18. Id. at 9-15.

19. Id.

20. Off. of Institutional Research and Off. of Student Research, Camipus Statisilcs for the Univ. of Cal. at Berkeley Fall 1987, at 1-2 (1987).

21. AUditor GeNeral's REPORT, supra note 8 , at 48 .

22. According to the admissions criteria established by the state legislature, $15.8 \%$ of 1986 Caucasian high school graduates, compared to $32.8 \%$ of Asian graduates, were eligible for freshmen admissions to the U.C. system. California Postsecondary EduCATION Commission, Eligibilit y ok California's 1986 High School Graduates for Admission to its Pubi.ic Universitifs 15 (Mar. 21, 1988). See infra texi accompanying notes 113-14.

23. HaRVARD REPORT, supra note 10 , at Table 2 . Harvard's academic ratings are based on high school grades, recommendations, essays, and standardized test scores. Id. at 8 . Stanford bases uts academic ratings on grades, rigor and quality of high school programs, and test scores. A confidential study found that even when the academic ratings of Asians and Caucasians are equal, Asians are admitted at a lower rate. STANFord UnIversity, CUAFA SUBCommitTeE REPORT ON ASIANAmerican Admissions Table 5 (Feb. 23, 1986) [hereinafter CUAFA Subcommtree] (un file with author). 
tion process. ${ }^{24}$ The available evidence on academic performance of Asians undermines this presumption and suggests that scholastic ability cannot account for the discrepancy in admit rates.

\section{Non-academic Qualifications of Asian American Applicants}

Some university officials argue that while Asian Americans score high on academic ratings, they perform less well on personal ratings. ${ }^{25}$ According to these administrators, Asian candidates tend to concentrate in the sciences or seek admissions to highly selective programs, are less wellrounded, and generally score lower on non-academic qualifications. Each of these claims is based on questionable racial stereotypes.

\section{Intended Majors}

An applicant's intended major is not an explicit criterion for admissions to Stanford, Harvard, or Brown. ${ }^{26}$ Even if the tentative selection of a competitive major was to account for the low Asian admit rate, the rates for Asian applicants should be approximately equal to admit rates for Caucasians within that major. A confidential Stanford report found, however, that for every category of intended majors, Asian Americans had a lower admit rate than Caucasians for the Class of $1989 .{ }^{27}$

Brown's Director of Admissions has stated that the low Asian admit rate is caused by the overwhelming number of Asians applying as "premeds." ${ }^{28}$ In response, the Asian American Students Association has alleged that the Director has never defined what constitutes a "pre-med;" instead, he bases his determination on subjective considerations and stereotypes of Asian applicants. ${ }^{28}$ Brown's Faculty Committee on Minority Affairs (COMA) rejected the myth that there are too many Asian "pre-

24. F.g. "The primary criterion for admission is academic excellence." STANFORD Today, supra note 8 , at 108 .

25. The decision-making process at Harvard relies on academic qualifications and "personal qualities and character." Harvard University. Official. Register of Harvard University 1988-89, al 19 (1988) [hereinafter HaRvard Recister]. Stanford relies on "academic excellence" and "personal achievement." STANFORD TODAY, supra note 8, at 108 . Brown requires high school counselors to et aluate candidates on the basis of "intellectual ability and achievement," and "character and personality." Brown Liniverstiy. Application to the College $2 A$ (1988-89) (hereinafter BRown APlIICATION).

20. "An applicant's intended major is not taken into account when we make our admissions decisions" SI 4NFORD TODAY, supra note 8 , at vi. "[A] student's academic preference does not limit his chances for admission." HARVARD REPORT, supra note 10, at 10. "University policy dictates that no candidate for admissions be denied solelv on the basis of the degree program for which he or she seeks consideration." Brown APpI ICATION, supra note 25, at 16.

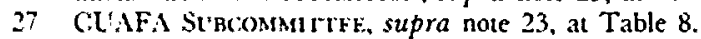

28 "The sast majority of Asian-Americans applying here, 70 to 75 percent, are premedical students." according to Brown's Director of Admissions. "The question is not one of race, it's academic balince " Asan-Americans Question Izy League's Entry Policies, N.Y. Times, May 30, 1985, at B1, col 3. Brown's internal staustics reveal that only $30 \%$ of $A$ sian applicants for the Class of 1986 were prentedical students. A.IS.1 RFPOR r, supra note 13, at Table 7.

20. Brown Daily Herald. May 8. 1986, at 10. col. 3. 
meds" and found that the "claim results from a reliance on inference and not necessarily on the declared [major] of the applicant."

Berkeley administrators have also suggested that the low Asian admit rate is caused by the high number of Asians applying to the College of Engineering. ${ }^{31}$ Yet in Berkeley's two largest engineering departments, Caucasian admit rates still exceeded Asian admit rates in all seven years

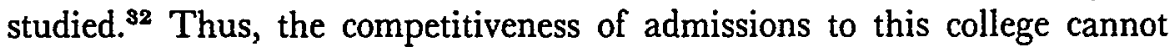
account for the disparity between Asian and Caucasian admit rates. ${ }^{33}$

\section{Extracurricular Activities}

Admissions officers have claimed that Asians participate in fewer extracurricular activities in high school than their Caucasian counterparts, ${ }^{34}$ and have characterized Asian applicants as "one-dimensional."35 Stanford, which assigns each applicant a "non-academic rating" based on extracurricular achievements, found generally that even when Asians and Caucasians received the same non-academic rating, Asians were still admitted at a lower rate to the Class of $1989 . .^{36}$ Other studies of Asian American high school students, while not describing the specific extracurricular achievements of applicants to Harvard, Brown, and Berkeley, refute the stereotypical perception that Asians avoid extracurricular activities. ${ }^{37}$

\section{Personal Ratings}

The third and most problematic rationale offered by admissions officers for the disparity is that Asian Americans score lower on personal ratings. ${ }^{38}$ Such judgments are inherently subjective, relying on the admissions officers' interpretation of personal essays, extracurricular activities, high

30. Brown University, Report to the Corp. Comm. on Minority Affairs From Its SubComm. on Asian American Admissions 3 (Feb. 10, 1984) [hereinafter COMA Report].

31. When Being Best Isn't Good Enough, L.A. Times, July 19, 1987, (Magazine), at 28.

32. The disparity in admit rates between Asian and Caucasian Engineering applicants varied from a high of $10.7 \%$ in 1983 , to a low of $2.2 \%$ in 1987 . AuDITOR GENERAL's RePORT, supra note 8 , at $58-65$.

33. Statistics from UCLA also reveal that the Asian admit rate to the School of Engineering is consistently lower than the Caucasian admit rate. Nakanishi, supra note 4, at 22 .

34. Biemiller, Asian Students Fear Top Colleges Use Quota System, Chronicle Higher Educ., Nov. 19,1986 , at 34 .

35. COMA REPORT, supra note 30 , at 9.

36. CUAFA SubcommitTe, supra note 23 , at Table 5.

37. A Department of Education study of 58,000 high school students found that $13 \%$ of Asian Americans participated in band or orchestra compared to $14 \%$ of Caucasians. Asians had a $30 \%$ participation rate in varsity athletics compared to $34 \%$ for Caucasians. The rates for debating or drama were $9 \%$ and $13 \%$, respectively. Asians, however, had higher participation rates for student government (21\% versus $16 \%$ for Caucasians) and honorary clubs (28\% versus $17 \%$ for Caucasians). Peng, School Experiences and Performance of Asian-Pacific american High School. StUDENTs Table 9 (1984) (U.S. Dept. of Education publication). Profiles of SAT candidates also indicated that "Asian-American students [were] more likely to participate in social, ethnic, or community organizations" than other SAT candidates. The Coll.egre BoARd, Profil.fs, Col.t.fGk-Bound SENIORS, 1985, at xix [hereinafter 1985 SAT Profiles].

38. COMA REPORT, supra note 30 , at 4. 
school recommendations, and reports of interviews conducted by admissions officers or college alumni. Brown's COMA discovered that Asian applicants received comparatively low personal ratings, but concluded that the "unjustified low ratings are due to the cultural biases and stereotypes which prevail in the admissions office. Such biases and stereotypes prevent admissions officers from appreciating and accurately evaluating the backgrounds and nuances of the Asian American cultural experience."39

Stanford's Committee on Undergraduate Admissions and Financial Aids (CUAFA) found that academic and extracurricular ratings, declared majors, legacies, ${ }^{10}$ athletics, and geographic origin could not account for the low Asian admit rate. ${ }^{41}$ Implicitly, the only remaining explanation was that Asians received lower personal ratings. The Committee concluded that there were real or perceived differences ${ }^{\mathbf{4 2}}$ in the subjective materials and/or that "unconscious biases have influenced the admissions decisions." ${ }^{\prime 3}$

While colleges may pursue legitimate goals through their admissions processes, the use of personal ratings has a disparate impact on Asian applicants. Such criteria should be a principal focus of a legal challenge.

\section{Legal Analysis}

An Asian American plaintiff could predicate her cause of action on either a statutory or a constitutional theory. Supreme Court jurisprudence suggests that a case filed under Title VI regulations, ${ }^{44}$ which incorporate a disparate impact standard, would offer the greatest possibility of success. The admissions practices of the three private universities serve as examples for this legal theory, although a suit against a public institution should also include a Title VI disparate impact claim.

The constitutional theory, based on the equal protection clause of the Fourteenth Amendment, ${ }^{45}$ is another means for attacking upper limit quo-

39. Id.

40. Children of alumni, and at times faculty, are categorized as legacies and receive preferences in the admissions process.

41. CUAFA REPORT, supra note 16, at 14, col. 2.

42 '[D]escriptions of 'focused interest,' especially in science or engineering, might be interpreted positively when applied to whites ('the student delves deeply into one topic and learns it thoroughly'), and negatively when applied to Asian Americans ('the student has narrow interests'). Id. at 14, col. 3.

43. Id. After the extensive study, Stanford's Asian admit rates, which were previously only $65 \%$ to $70 \%$ of Caucasian admit rates, rose to $89 \%$ of Caucasian rates for the Class of 1990 . Bunzel \& Au, Dizersity or Discrimination? Asian Americans in College, PuB. INrerest, Spring 1987, at 61.

44. According to Title VI regulations issued by the Department of Education, recipients of federal lunding may not "utilize criteria or methods of administration which have the effect of subjecting Individuals to discrimination because of their race, color, or national origin, or have the effect of defeating or substantially impairing the accomplishment of the objectives of the program as respect to [sic] individuals of a particular race, color, or national origin." 34 C.F.R. $\$ 100.3(\mathrm{~b})(2)$ (1987) (emphasis added). Other sources of federal funding use identical language in their regulations. See, e.g., 45 C.F R. $\$$ 611.3(b)(2) (1986) (NSF); 45 C.F.R. $\S 1110.3(b)(2)$ (1986) (NFAH); 14 C.F.R. § 1250.103-2(b) (1987) (NASA).

45. "No state shall ... deny to any person within its jurisdiction the equal protection of the 
tas at public institutions. Such a claim would require a demonstration of discriminatory intent. While the constitutional analysis will focus on Berkeley's admissions policies, its significance for private universities should not be disregarded, since a suit filed on the basis of Title VI ${ }^{46}$ as distinguished from Title VI regulations, would require a showing of intent identical to the constitutional standard. ${ }^{47}$

\section{A. The Legacy of Racial Discrimination}

Both the equal protection clause and Title VI are designed to protect against discrimination on the basis of race or national origin. While Asian Americans are entitled to such protection, these formal rules have not been applied as rigorously to safeguard the rights of Asian Americans throughout most of American history. For example, in Korematsu $v$. United States, ${ }^{48}$ the Court purportedly applied strict scrutiny, the most exacting level of judicial review, but nonetheless upheld the mass internment of 110,000 Japanese Americans during World War II on the basis of "military urgency." 49 In stark contrast, Germans and Italians were subject to individual review. ${ }^{50}$ This fact, combined with the legacy of state-sponsored discrimination against Asians, ${ }^{51}$ forms the backdrop to the allegations of upper-limit quotas on Asian American applicants.

laws." U.S. CoNST. amend. XIV, $\$ 1$. Enforcement actions against public institutions should be brought under 42 U.S.C. $\S 1983$ (1981).

46. "No person in the United States shall, on the ground of race, color, or national origin, be excluded from participation in, be denied the benefits of, or be subjected to discrimination under any" program or activity receiving Federal financial assistance." Civil Rights Act of $1964, \S 601,42$ U.S.C. $\$ 2000 d$ (1982). See infra note 64 .

47. Thus, a suit against a private university that receives federal funds would be based on Title . VI and Title VI regulations. A suit against a public university, in contrast, would be filed under the equal protection clause, Title VI, and Title VI regulations. This Note does not address the alternative of seeking administrative review under Title VI. See 34 C.F.R. \$100.7-8 (1987).

48. 323 U.S. 214 (1944).

49. Id. at 223 .

50. U.S. Commission on Wartime Relocation and Internment of Civilians, Personal. Justic: Denikd 283-89 (1982).

51. Since the 1850's, Asian Americans have been repeatedly subjected to state-sponsored discrimination. See, e.g., Yick Wo v. Hopkins, 118 U.S. 356 (1886) (San Francisco laundry ordinance held unconstitutional); Queue Ordinance (1871) (cropping hair of every male prisoner contrary to Chinese customs); Cubic Air Ordinance (1870) (requiring lodging houses to provide space exceeding average footage in Chinatown); Chinese Head Tax (1852) (taxing all Chinese over age 18 who were not already paying a tax). See E. SANDMEYer, The ANTI-Chinese Movement in California $50-55$ (1939). In People v. Hall, 4 Cal. 399 (1854), Chinese were prohibited from testifying against Caucasians in either civil or criminal proceedings; thus, crimes perpetuated against Chinese residents went unpunished if no Caucasian would act as a witness. At the federal level, immigration laws deemed Chinese and Japanese immigrants "aliens ineligible for citizenship" and excluded immigrants from both nations. See E. SANDMFYER, supra, at 96-105; Hune, supra note 6, at 283-86. In education, the "separate but equal" doctrine for Asian Americans in education was sanctioned by the United States Supreme Court in Gong Lum v. Rice, 275 U.S. 78 (1927). States such as California did not repeal statutes segregating Asian students until 1947. Guey Heung Lee v. Johnson, 404 U.S. 1215 (1971). See V. Low, The Unimpressible Race: A Century of Educational, Struccile bi the. ChiNHSE IN SAN Fravcisc: (1982). Recent incidents of violence directed against Asian Americans, while not state-sponsored, indicate the persistence of anti-Asian sentiments in the United States. U.S. Commission on Civil. Ricihts, Recient Activity Against Cirizens and Rrsidents of Asian De- 
Quotas on the admissions of identifiable minorities are also a part of America's past. The current claims bring to mind the quotas imposed on Jewish students at Harvard, Yale, Princeton, and Columbia beginning in the 1920 's. ${ }^{52}$ University officials used similar techniques such as personal ratings, and stated similar reasons such as the need to preserve college traditions and student body diversity to justify the limitations. ${ }^{53}$ Historic discriminatory practices are now directed at the newest immigrant group to challenge the racial composition of highly selective institutions.

\section{B. The Standard for a Title VI Claim}

The legislative history of Title VI fails to provide clear guidance on the meaning of "discrimination," 54 but subsequent Supreme Gourt decisions, beginning with Lau $v$. Nichols, ${ }^{\text {ss }}$ have clarified the standard for a Title VI claim. The Lau Court adopted the effects test for Title VI, ${ }^{56}$ relying on regulations issued by the Department of Health, Education, and Welfare. ${ }^{57}$ Although $B a k k e$ cast doubt on the continuing validity of $L a u,{ }^{58}$ seven Justices in Guardians Association v. Civil Service Commission of New York ${ }^{58}$ agreed that the Title VI standard is identical to the constitutional standard-both require proof of discriminatory intent. ${ }^{60}$ However, five Justices concluded that proof of disparate impact is sufficient to estab-

SCEvT $(1986)$

52. In 1926, Harvard reduced its Jewish enrollment from about $25-27 \%$ to about $10-16 \%$, and the Committee on Admissions continued to make references to "the quota" in 1942. M. SYNNOTT, The Half Opened Door: Discrimination and admissions at Harvard, Yale, and Princeton, 1900-1970, at 20, 112 (1979); D. Oren, Joining the Club: a History of Jews and YAt.k (1985)

53. President Lowell of Harvard argued for controlled racial mixing so that Jews, "a group which is not easily assimilated," would not undermine the position of old-stock Americans in the college and threaten college tráditions. M. SynNotr, supra note 52, at 57, 59,64. Admissions officers today point to "conflicts between the cultural patterns of Asian families and the educational traditions and administrative goals of American colleges." Biemiller, supra note 34, at 1 .

54. During the congressional debates, it was unclear whether Title VI was meant to incorporate the cunstitutional standard for discrimination or whether it relied on some other philosophical grounds. The final political compromise required each federal agency to promulgate regulations for its programs, suggesting that Congress delegated to the agencies the authority to define the meaning of discrimunation under Title VI. See Abernathy, Title VI and the Constitution: A Regulatory Model for Defiung "Discrimination," 70 GEO. L.J. 1, 20-39 (1981); Civil Rights, Hearings on HR 7152 Before the House Comm. on the Judiciary, 88th Cong., 1st Sess. 1520-21, 1890, 2740 (1963).

55. 414 U.S. 563 (1974) (failure of school system to provide English instruction to non-English peaking Chinese students denies meaningful opportunity to participate in public educational programs in violation of Title VI).

50 "Discrimination is barred which has that effect even though no purposefnl design is present

"Jd. al 568 (emphasis in original).

57 Id at $560-67$

5s. Ironically, Justices Brennan, White, Marshall, and Blackmun, in seeking to uphold the validIt) of the university's preferential admissions program, equated the Title VI standard for discriminativit with the constitutional standard, thereby requiring proof of intent and narrowing the scope of Tule VI protections. Bakke, 438 U.S. at 325, 331 (Brennan, White, Marshall, and Blackmun, JJ.). 3) 463 U.S. 582 (1983).

61. Id. at 610 (Powell, J., joined by Burger, C.J., and Rehnquist, J., concurring); id. at 612 (G'Connor, J., concurring), id. at 640-42 (Stevens, J., joined by Brennan and Blackmun, JJ., dissenting). 
lish a violation under the regulations adopted pursuant to Title VI. ${ }^{61} \mathrm{~A}$ unanimous Court in Alexander $v$. Choate ${ }^{82}$ clarified the apparent contradiction by reading Guardians to hold that "Title VI itself directly reached only instances of intentional discrimination," but "actions having an unjustifiable disparate impact on minorities could be redressed through agency regulations designed to implement the purposes of Title VI." ${ }^{63}$

Although Title VI applies to the admissions practices of private universities that receive federal funds, ${ }^{64}$ an Asian plaintiff would stand a greater chance of success by filing a suit under Title VI regulations. ${ }^{65}$ Since Guardians, six circuits have stated that a cause of action premised on Title VI regulations does not require proof of discriminatory intent. ${ }^{86}$

\section{Admissions Practices of Private Universities Subject to Attack}

An Asian American plaintiff must allege that specific admissions practices or policies have a disparate impact on Asian applicants; this Section examines two such practices.

\section{a. Personal Ratings}

An Asian plaintiff could plead that the facially nondiscriminatory personal ratings employed by Stanford, Harvard, and Brown have a disparate impact on Asian candidates and are not related to educational performance. An applicant could also rely on the findings of investigations at

61. Id. at 592-93 (opinion of White, J.); id. at 618-24 (Marshall, J., dissenting); id. at 642-43 (Stevens, J., joined by Brennan and Blackmun, JJ., dissenting).

62. 469 U.S. 287 (1985) (consideration of $\$ 504$ of Rehabilitation Act, which Congress modeled after Title VI, prompted review of scope of Title VI).

63. Id. at 293 (footnote omitted).

64. Congress amended the "program or activity" language of Title VI to "mean all the operations [of] . . . a college, university, . . . or a public system of higher education." Civil Rights Restoration Act of 1987, Pub. L. No. 100-259, $\S 606,102$ Stat. 28-32 (1988). Admissions practices of private universities are part of their overall operations and could fail within the scope of the Act.

65. See supra note 44 and text accompanying notes $62-63$. Universities are also prohibited from treating "an individual differently from others in determining whether he satisfies any admissions, enrollment . . . or other requirement." 34 C.F.R. $\$ 100.3$ (b)(1) (1987).

66. See Larry P. v. Riles. 793 F.2d 969 (9th Cir. 1986) (IQ tests with discriminatory effect on enrollment of Black children violated Title VI regulations). Five other circuits have acknowledged the availability of a claim under Title VI regulations, but plaintiffs failed to allege specific practices or policies which caused the disparate impact. Latinos Unidos de Chelsea v. Secretary of Hous., 799 F.2d 774, 784-85 n.20 (1st Cir. 1986) ("under the regulations, plaintiffs must show a discriminatory impact"); Castaneda v. Pickard, 781 F.2d 456, 465 n.11 (5th Cir. 1986) ("Title VI action can now be maintained . . . in the guise of a disparate impact case . . [where] proof of discriminatory intent is not necessary"); Craft v. Board of Trustees of Univ. of Ill., 793 F.2d 140, 142 (7th Cir ), cert. denied. $107 \mathrm{~S}$. Ct. 110 (1986) ("Title VI reached non-intentional discrimination because agency regulations implementing Title VI prohibited the expenditure of federal funds in a manner that had a discriminatory impact"); Mabry v. State Bd. of Community Colleges, 813 F.2d 311, 317 n.6 (10th Cir. 1987) ("a bare majority of the Supreme Court [in Guardians] upheld the validity of Title VI regulations

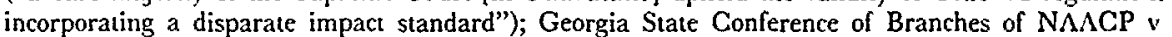
State of Ga.. 775 F.2d 1403, 1417-18 (11th Cir. 1985) (In Guardians, "five Justices were of the opinion that the regulations promulgated under Title VI permit the filing of suits alleging a disparate impact theory"). 
Brown $^{67}$ and Stanford ${ }^{88}$ if she were to file suit against either institution. Both reports, based on testimonies of admissions officers, acknowledge the existence of conscious or unconscious biases against Asian applicants, as reflected in low personal ratings, and suggest that such biases may influence admissions decisions at other universities.

\section{b. Benchmark System}

Some highly selective universities have used "historic benchmarks" or target systems $\mathrm{s}^{\mathbf{\theta}}$ to determine the composition of each entering class. A Brown study ${ }^{70}$ revealed that the use of such benchmarks by the admissions office served to perpetuate the existing racial composition of the university, to the detriment of rapidly expanding groups within the applicant pool. Each fall, the admissions office establishes a set of enrollment goals based on the structure of previous year's matriculating freshman class. The number of admittees is monitored throughout Brown's admissions season to ensure that the relative proportions of identifiable groups, such as athletes, minorities, and alumni children, remain fairly constant from year to year. However, this type of admissions process fails to account for demographic changes. As a result, the use of benchmarks at Brown ${ }^{71}$ has a detrimental impact on Asians, the fastest growing applicant group. ${ }^{72}$

\section{Potential Defenses of Private Universities}

The defenses which highly selective universities may assert are unknown since this sort of claim has not yet been litigated. However, several likely defenses can be anticipated.

\section{a. Personal Rctings Serve an Educational Purpose}

Once a prima facie case has been established, the burden of proof shifts to universities to "demonstrate that the requirement which caused the dis-

67. "All admission officers confirmed that such biases and stereotypes function negatively in the admission process for Asian Americans." COMA REPORT, supra note 30, at 4.

68. "[E]thnic stereotyping might inter-act with subjective ratings in the minds of readers to create an aggregate portrait that is unintentionally detrimental to Asian Americans." CUAFA REPOR'T, supra note 16, at 14, col. 3 .

69. Yale's Dean of Admissions refers to a "target" system or expected distribution within each freshmen class. Chang, Yale Dean Defends Policy on Asian Admissions, Blaci Issues in Higher Enucation, Nov. 15, 1985, at 6, cited in J. Hsia, Asian Americans in Higher Education and AT WORK 94 (1988).

70. COMA REPORT, supra note 30 , at $2-3$.

71. Similar allegations of using benchmarks have been directed at Harvard. Neer, Harvard Official Denies Allegation that Quota Imposed, Boston Globe, Dec. 7, 1985, at 23, col. 1. See supra note 15 for Harvard admit rates. The U.S. Department of Education is currently investigating the admissions processes at Harvard and UCLA to ensure compliance with the nondiscriminatory provisions of Title VI. Harvard and U.C.L.A. Face Inquiries on Quotas, N.Y. Times, Nov. 20, 1988, at 28, col. 1.

72. See supra notes $7 \& 14$ and infra note 128 . 
proportionate impact was required by educational necessity."73 Highly selective universities may argue that one of their major objectives is to train future leaders, ${ }^{74}$ and that subjective standards permit admissions officers to evaluate this potential. If so, personal ratings should bear some correlation to this goal. However, it is not clear that interviews, personal essays, or recommendations can adequately evaluate personal traits, much less predict an applicant's future contributions to society. In fact, studies have demonstrated that personal ratings used by admissions offices have little predictive power for assessing a candidate's future success. ${ }^{75}$ Furthermore, the history of Jewish admissions reveals that while similar reasons were used to support the adoption of subjective criteria in the 1920's, universities intended to use the measures for exclusionary purposes. ${ }^{76}$

\section{b. Legacy and Athletic Admissions}

Harvard and other selective universities have stated that low Asian admit rates result partially from the "very few Asian-Americans in our applicant pool who are alumni/ae children or prospective varsity athletes." The relationship between an athletic program and the institutional purpose of a highly selective college is ambiguous, although a winning football team may induce alumni donations to the general fund. ${ }^{78}$ Admissions of alumni children, however, may be justified by legitimate financial concerns because these admissions often encourage alumni contributions. While catering to current alumni without weighing the future contribu-

73. Larry P. v. Riles, 793 F.2d 969, 982 (9th Cir. 1986). In the context of Title VII, the Supreme Court recently held that disparate impact analysis may be applied to subjective employment criteria. A plurality opinion, though, stated that only the burden of production, not proof, shifts to the em- ployer. Watson v. Fort Worth Bank \& Trust, 108 S. Ct. 2777, 2790 (1988). However, the Court has been reluctant to consider Title VII and Title VI as interchangeable. See, e.g., Johnson v. Transportation Agency, 107 S. Ct. 1442, 1450 n.6 (1987) ("Title VII and Title VI, therefore, cannot be read in pari materia.").

74. Harvard and Stanford catalogues specifically refer to the goals of leadership training and student body diversity. HARvard REGISTER, supra note 25, at 19; STANFORD TODAY, supra note 8, at 108.

75. For a summary of studies and criticism of the use of non-academic variables, see R. KLITGaARD, Choosing Elites 134-41 (1985).

76. In 1926, the Harvard Board of Overseers recommended that "the rules for the admission of candidates be amended to lay greater emphasis on selection based on character and fitness and the promise of greatest usefulness in the future." M. SYNNOTT, supra note 52, at 109. President Lowell stated that any test of character "passed with the intent of limiting Jews should not be . . . applicable to Jews and Gentiles alike." Id. at 63.

77. Statement on Asian-American Harvard-Radcliffe Admissions, Harvard Gazetie, Jan. 22, 1988, at 5, col. 3; Asian-Americans Question Ivy League's Entry Policies, supra note 28, at B4, col. 3 (discussing Princeton). The admit rate for legacies and athletes to Brown's Class of 1991 was $46 \%$ and $56 \%$ respectively. UNDERgRAduATE Admissions, supra note 14 , at $30-31$. In contrast, Stanford concluded that "the overrepresentation of whites among special groups such as alumni legacies, faculty/staff children, and athletes did not work to account for the differential rate of admission except in a relatively minor way." CUAFA REPORT, supra note 16, at 14, col. 2 .

78. While sports victories are correlated with contributions to the universities' athletic programs, several studies have found that there is "no significant relationship" between wins and increased alumni donations to the universities' general funds. Do Winning Teams Spur Contributions?, Chronicle Higher Educ., Jan. 13, 1988, at A32, col. 3. 
tions of potential Asian alumni is shortsighted, this may be the strongest defense available to a university. ${ }^{78}$

Despite the strength of this argument, universities may hesitate to use this defense because efforts to justify the rejection of competitive Asian applicants solely on the basis of legacy and athletic admissions would portray highly selective universities as institutions that cater to their alumni and football coaches in pursuit of increased donations. This concession could severely undermine the image of a meritocratic admissions process which highly selective universities seek to project to society at large. ${ }^{80}$

\section{c. Diversity}

Justice Powell advocated diversity ${ }^{81}$ as a legitimate justification for preferential admissions on the ground that a diverse student body promotes an "atmosphere of 'speculation, experiment and creation." "82 Since $B a k k e$, universities have successfully relied upon diversity to validate such programs, ${ }^{83}$ and they are likely to raise diversity as a defense to allegations of an upper limit on Asian Americans. ${ }^{84}$ According to an assistant dean at Harvard, admissions officers at prestigious institutions have contended that "further increases of Asians would diminish the diversity of students for which [these universities] strive" and have suggested that the Asian applicant pool is "too homogeneous."

Such statements distort the concept of diversity; Justice Powell advocated a program in which "race or ethnic background may be deemed a 'plus' in a particular applicant's file, yet it does not insulate the individual from comparison with all other candidates for the available seats." ${ }^{186}$ Such a program would not grant or deny admissions solely on the basis of an

79. A plaintiff could, however, allege that alumni preferences "perpetuate past patterns of discrimination," giving preferences to "rich and powerful" groups which include a disproportionately small number of minorities. Dershowitz \& Hanft, Affirmative Action and the Harvard College Diversity-Discretion Model: Paradigm or Pretext, I Cardozo L. REv. 379, 410 (1979).

80. See supra notes 24-25.

81. Diversity was initially invoked by Columbia to reduce the number of Jewish students from New York and the Northeast. H. Wechsler, The Qualified Student: A History of Selective COL.L.:E: AdMISSION IN AMERICA 149-50, 153 (1977).

82. Regents of Univ. of Cal. v. Bakke, 438 U.S. 265, 312 (1978) (Powell, J.).

83. DeRonde v. Regents of the Univ. of Cal., 28 Cal. 3d 875, 172 Cal. Rptr. 677, 625 P.2d 220, cert. denied, 454 U.S. 832 (1981) (minority admissions program at Davis Law School upheld to ensure diversity of student body or to mitigate effects of past discrimination). U.C. successfully argued that "an appreciable minority representation in the student body will contribute 'to] a valuable cultural diversity for both faculty and students . . ." 172 Cal. Rptr. at 680, 625 P, 2d at 223; see also McDonald v. Hogness, 92 Wash. 431, 598 P.2d 707, 713 n.8 (1979), cert. denied sub nom. McDonald v. Gerberding, 445 U.S. 962 (1980) (university's statement in defense of its minority admissions program reflected "a purpose of promoting diversity in the student body").

84. One Harvard admissions officer stated, "It is the diversity element that hurts most of the Asian applicants because many who apply are pre-medical, science, technical types." Ho \& Chin, Admissions Impossible, Brinc;., Summer 1983, at 8. See supra notes 28-33 and accompanying text.

85. Hassan, Asian American Admissions: Debating Discrimination, 142 C. BoARD Rrv. 18, 43-44 (Winter 1986-87).

86. Bakke, 438 U.S. at 317 (Powell, J.). 
applicant's race, but would consider a "broader array of qualifications and characteristics." Us7 Using diversity as a justification for limiting Asians, however, implies that an Asian applicant's contribution to diversity derives solely from her race, and that her value is negated by the presence of too many others of her color; her "plus" ceases to exist and instead acts as a negative. For institutions that purport to base admissions decisions on individual attributes, this is a clear contradiction.

Furthermore, Justice Powell certainly did not intend diversity to be used as a justification for discrimination against racial minorities. Efforts to limit the number of Asian admittees do in fact "establish a quota in the invidious sense of a ceiling on the number of minority applicants to be admitted."88 Universities have distorted diversity, transforming what was intended to be a shield for preferential admissions ${ }^{89}$ into a sword against a minority group seeking admissions.

\section{d. Overrepresentation}

One dean at Harvard voiced a related theme, which may be used as a defense against allegations of a quota, by stating that Asian Americans are "no doubt the most over-represented group in the university." claims of Asian "overrepresentation" suggest that administrators have some ideal racial balance in mind, partially based on census figures and on the benchmark system, but not on the differential SAT test-taking rates between Asian Americans and Caucasians.91

First, institutions like Harvard fail to apply the concept of national representation consistently, ${ }^{92}$ and as history reveals, identical reasons were used to impose a quota on Jewish students. ${ }^{93}$ Furthermore, if admissions

87. Id. at 315 (Powell, J.).

88. Id. at 375 (Brennan, White, Marshall, and Blackmun, JJ.). Justice Powell also found this type of "two-track" or "multitrack" system legally impermissible. Id. at 315 (Powell, J.). With a limited number of slots available under a particular "track" or quota, Asian Americans compete against each other for positions and are insulated from other segments of the applicant pool; this practice imposes higher standards on Asian applicants than on Caucasian applicants.

89. Commentators now claim that affirmative action for Blacks and Hispanics accounts for the lower Asian admit rates. Gibney, The Berkeley Squeeze, New Republic, Apr. 11, 1988, at 17. If this were the case, the impact of such programs should fall evenly on both Caucasians and Asians, but see supra notes 14-17 and accompanying text, unless universities are placing a quota on the total number of minorities admitted, so that increases in Black and Hispanic admissions affect only Asians.

90. Butterfield, Harvard's 'Core' Dean Glances Back, N.Y. Times, June 2, 1984, at 8, col. 1 (quoting Dean Rosovsky).

91. In $1985,70 \%$ of Asian American 18-year-olds took the SAT, compared to $30 \%$ of Caucasian 18 -year-olds, and $28 \%$ of all 18 -year-olds. 1985 SAT Profiles, supra note 37 , at vii. While testtaking rates do not indicate the number of applicants to each institution, they do provide a more accurate picture of the college-age population or potential applicants than the U.S. census.

92. Harvard no longer uses "overrepresentation" to reduce its $25-33 \%$ Jewish student population down to the $3 \%$ that Jews represent in the general population, nor does it limit the numbers of alumni children to their overall national representation. For a similar observation, see AASA REPORT, supra note 13 , at 20 .

93. In 1924, Princeton decided not to accept any more than the percentage of Jews in the national population, roughly three percent, and used this quota to reduce by half the number of Jewish stu- 
are determined by current census figures, such practices would perpetuate the history of "[r]acism in U.S. immigration policy." Using "overrepresentation" to justify limits on Asian admissions perpetuates the denial of equal opportunity for Asian Americans.

\section{B. The Standard for an Equal Protection Claim}

The constitutional standard requires evidence of discriminatory intent or purpose in order to establish a violation of the equal protection clause and, following Guardians, Title VI. The decisionmaker must have "selected or reaffirmed a particular course of action at least in part 'because of,' not merely 'in spite of,' its adverse effects upon an identifiable group." clause must demonstrate that impermissible motives, not the neutral explanations offered, account for the university's action..$^{96}$ The intent requirement is a formidable barrier, raising questions such as whose intent is relevant and how much illicit intent is required. A court will inquire into "circumstantial and direct evidence of intent as may be available," including whether the official action bears more heavily on one race than another, whether a clear pattern emerges, whether the sequence of events reveals the decisionmaker's purpose, whether decisionmakers departed from normal procedures or policies, and whether contemporaneous statements by parties involved shed light on motivation and intent. ${ }^{98}$

\section{Policies of a Public University Subject to Attack}

At Berkeley, the sharp decline in the number of newly enrolled Asian Americans from 1,303 in 1983 to 1,031 in 1984, a $20.9 \%$ drop in one year, suggested that new admissions policies may have been adopted. ${ }^{99}$

dents admitted. M. SYNNOTT, supra note 52, at 20.

94. Hune, supra note 6, at 283. Since historically Asian immigrants were excluded from America, or restricted to an annual quota of 100 per country, the growth and current size of the Asian American population has been artificially constrained.

95. Personnel Adm'r v. Feeney, 442 U.S. 256, 279 (1979)

96. Binion, "Intent" and Equal Protection: A Reconsideration, 1983 Sup. Cr. Rev. 397 (criticizing Supreme Court's use of intent to narrow protection provided by equal protection clause).

97. Arlington Heights v. Metropolitan Hous. Dev. Corp., 429 U.S. 252, 266 (1977).

98. Id. at 266-68. Rogers v. Lodge, 458 U.S. 613 (1982), and Hunter v. Underwood, 471 U.S. 222 (1984), provide additional guidance on how the intent requirement can be satisfied in the context of racial discrimination. The Rogers Court upheld the district court determination that the at-large electoral system, though "neutral in origin," was maintained for invidious purposes. 458 U.S. at 626-27. The Hunter Court found that a section of the Alabama Constitution would not have been adopted "in the absence of racially discriminatory motives." 471 U.S. at 231-32. Both cases reaffirmed the standards used in Arlington Heights and Washington v. Davis, 426 U.S. 229 (1976), recognizing that "discriminatory intent need not be proved by direct evidence" but can be "inferred from the totality of the relevant facts." Rogers, 458 U.S. at 618.

99. AsIan AMERICAN TASK ForCe ON University ADMISSIONS, TASK Force RePORT 6 (June 17, 1985) (Univ. of Cal., Berkeley). The percentage of Chinese American freshmen enrolled dropped $30 \%$ from 1983 to 1984, while the number of Caucasian freshmen declined only 6\%. BERKELEY Office of the Chancellor, Report on 1984 Enrollments of Chinese Students 1 (Dec. 5, 
The Asian community alleged that Berkeley had instituted a minimum 400 SAT verbal score, a policy with a detrimental impact on immigrant Asians, to limit Asian admissions. ${ }^{100}$ While Berkeley may have a legitimate interest in assuring the English competence of its students, the Chancellor never acknowledged and repeatedly denied the existence of a minimum verbal score. ${ }^{101}$ Finally, under pressure from the Asian community, the Chancellor admitted that such a policy had indeed been adopted in 1984, but was withdrawn after a brief time. ${ }^{102}$ The dispute fueled suspicion that Berkeley had covertly adopted guidelines which, though neutral on their face, caused an inevitable or foreseeable drop in Asian American admissions. ${ }^{103}$

The decline in Berkeley's Asian enrollments can also be attributed to a 1984 decision, made without the participation of the faculty committee on Admissions and Enrollment, ${ }^{104}$ to remove the "protection" for Educational Opportunity Program (EOP) ${ }^{103}$ applicants and to "redirect" EOP students "who were not Black, Hispanic or Native American" to other U.C. campuses. ${ }^{108}$ This was the first time that EOP, a program designed to promote access to Berkeley for all economically disadvantaged students regardless of race, acquired a racial criterion. ${ }^{107}$ The decision affected three times as many Asians as Caucasians, ${ }^{108}$ since a larger proportion of Asian applicants come from disadvantaged backgrounds. ${ }^{109}$ While disparate impact is not "the sole touchstone of an invidious racial discrimination,"110 such policy changes, accompanied by the disparity between Asian and Caucasian admit rates over a seven year period, suggest that Berkeley may have intended to decrease the number of Asians admitted.

. 1984) [hereinafter 1984 Enrol.lments of Chinkst: Siunents].

100. A 1983 Berkeley report found that over a five year period, the mean $S A T$ verbal scores of immigrant freshmen who were predominately Asian oscillated around 400, a score at least 100 points lower than all other accepted applicants. N. Tang, Immigrant \& Refugee Students Project Report and Recommendations: 1983-84, at Table 3 (Mar. 22, 1983) (unpublished report) (on file with author).

101. 1984 ENRoI.IMFirts of Chinese Students, supra note 99, at 1.

102. Aoki, Asians Question UC Admissions Policy, CAl.. J., June 1988, at 259.

103. Personnel Adm'r v. Feeney, 442 U.S. 256, 279 n.25 (1979).

104. Lye, On the Asian Question, Berkflex Graduate, Dec. 1987, at 3-4.

105. Adopted in the 1960 's, EOP protects economically and educationally disadvantaged high school students who are U,C. eligible from being rejected or redirected to other U.C. campuses.

106. 1984 EnRot.lmenrs of Chinese Stunents, supra note 99, at 2.

107. L. Wang, Meritocracy and Diversity in Higher Education: Discrimination Against $\Lambda$ sian Americans in the Post-Bakke Era 15 (Nov. 19, 1987) (unpublished paper presented at Brown University) (on file with author).

108. "The number of Asian EOP applicants who were offered admission dropped from 183 of 197 (92.9 percent) in 1983 to 5.8 of 167 (34.7 percent) in 1984. Similarly, the number of Caucasians who were offered admission dropped from 41 of 45 ( 91.1 percent) in 1983, to 29 of 61 (47.5 percent) in 1984." AUdTrOR GiNERAL'S REPORT, supra note 8, at 48.

109. Berkeley's internal data show that $41 \%$ of Asian immigrant freshmen and $18 \%$ of all Asian freshmen, compared to $5 \%$ of Caucasian freshmen, came from families with parental incomes under $\$ 20,000$ (definition of economically disadvantaged under EOP). BERKFL.Y OFF. OF STUDFNI RFSFarc: 1985 Enitering; Fal.l. Freshmen with Low and Moderate. Estimated Annual. PaRFNTAL. INCOME (OCl. 29, 1986).

110. Washington v. Davis, 426 U.S. 229, 242 (1976). 
It is, however, unclear what weight the Supreme Court will give to statistical disparities in determining discriminatory intent. It appears that while statistical disparities can support a claim of discriminatory intent, the disparity has to be quite substantial before the Court will deem the state action violative of the equal protection clause. ${ }^{111}$

An Asian plaintiff can also allege that sudden policy changes provide evidence of discriminatory intent. ${ }^{112}$ U.C. administrators were aware that Asians performed well academically, but the percentage of students admitted on the basis of scholastic criteria alone declined from $60 \%$ in 1985 to $50 \%$ in 1986 to $40 \%$ in $1987,{ }^{113}$ without any explanation.

Furthermore, in response to the allegation that supplemental criteria (based on extracurricular activities, personal essays, and English and foreign language requirements) favored Caucasians, the Auditor General reviewed the Tier 2 supplemental criteria scores of 100 Caucasians and 100 Asians who applied to Berkeley in 1985 and 1986. The investigation showed that Asians had marginally higher supplemental scores than Caucasians in both years. ${ }^{114}$ If Asians in the applicant pool as a whole outscore Caucasians on both scholastic and supplemental criteria, no nondiscriminatory reason can account for the disparity in admit rates.

Finally, although he later stated that he was misinterpreted, ${ }^{115}$ the President of the University of California asserted in an interview that Asian Americans "are in the university well above their representation in the high school graduation pool," while Caucasian students are "underrepresented in the entering freshman classes."118 At another U.C. campus, UCLA's Director of Admissions explicitly recognized that such efforts to address the "under-representation" of Caucasians will reduce the numbers

111. Justice O'Connor, a swing vote on the Court, has suggested in the context of a Title VII reverse discrimination case that overwhelming numbers are required. At the Santa Clara County Transportation Agency, only 12 of 124 technicians, no skilled craft workers, and 1 of 110 road maintenance workers were women. Justice O'Connor deemed the severe statistical disparities sufficient to establish a violation of the equal protection clause, thus permitting the Agency to voluntarily adopt an affirmative action plan. Johnson v. Transportation Agency, 107 S. Ct. 1442, 1462-63 (1987) ( $O^{\prime}$ Connor, J., concurring). The Johnson majority disagreed with Justice O'Connor, stating that they would only require a showing of "manifest imbalance" before upholding the affirmative action plan. $107 \mathrm{~S}$. Ct. at 1452. It may be inferred, however, that all members of the Court would require more than a "manifest imbalance" in order to support an equal protection claim.

112. "Departures from the normal procedural sequence also might afford evidence that improper purposes are playing a role." Arlington Heights v. Metropolitan Hous. Dev. Corp., 429 U.S. 252, 267 (1977).

113. When Being Best Isn't Good Enough, supra note 31, at 25.

114. Auditor GENERAL's REPORT, supra note 8, at 50.

115. Astan Task Force Meets with UC President Gardner, East/West News, Mar. 19, 1987, at 1 , col. 2.

116. UC Fee Formula was Born of Student Fear of Huge Hikes, San Diego Union, Dec. 21, 1986, at C-7. The research coordinator for U.C. admissions services also stated that "Asians are overrepresented by almost three times their high-school population." Biemiller, supra note 34, at 36 . Finally, Berkelcy's Assistant Vice Chancellor warned that "if we keep getting extremely well-prepared Asians, and we are, we may get to the point where Whites will become an affirmative-action group." Bunzel, Affirmative-Action Admissions: How It "Works" at UC Berkeley, PUB. INTEREST, Fall 1988, at 127. 
of Asians admitted. ${ }^{117}$ While each piece of evidence alone may not be sufficient to establish discriminatory intent, the combination of all such factors may satisfy the constitutional standard. ${ }^{118}$

\section{Potential Defenses of a Public University}

After an Asian plaintiff establishes a prima facie case, Berkeley will have the opportunity "to rebut the presumption of unconstitutional action by showing . . . permissible racially neutral selection criteria . . .."119 Berkeley probably will seek to demonstrate that the use of minimum SAT scores and supplemental criteria, and the redirection of EOPs are necessary to improve academic qualifications or to increase student body diversity. The university may also rely on the athletic admissions and the overrepresentation defenses. ${ }^{120}$ However, the plaintiff need not show that the invidious purpose was the sole motivation, ${ }^{121}$ but that the new policies were adopted in part "because of" a desire to limit the number of Asian admittees. The existence of a permissible motive "would not render nugatory the purpose to discriminate . . .."122

\section{REMEDIES}

An Asian American plaintiff could seek an injunction ${ }^{123}$ against a university, whether public ${ }^{124}$ or private, to halt its discriminatory practices against Asian applicants. ${ }^{125}$ In certain circumstances, a request for dam-

117. "The campus will endeavor to curb the decline of Caucasian students . . . . A rising concern will come from Asian students and Asians in general as the number and proportion of Asian students entering at the freshman level declines-however small the decline may be." Memo from Rae Lee Siporin, UCLA Director of Admissions to Undergraduate Enrollment Committee (Dec. 10, 1984) (on - file, with author).

118. "[A]n invidious discriminatory purpose may often be inferred from the totality of the relevant facts, including the fact, if it is true, that the law bears more heavily on one race than another." Washington v. Davis, 426 U.S. 229, 242 (1976).

119. Id. at 241 (quoting Alexander v. Louisiana, 405 U.S. 625, 632 (1972)).

120. See supra notes 77-80, 90-94 and accompanying text.

121. Arlington Heights v. Metropolitan Hous. Dev. Corp., 429 U.S. 252, 265 (1977).

122. Hunter v. Underwood, 471 U.S. 222, 232 (1984).

123. For a comprehensive analysis of structural injunctions, see Special Project, Remedial Process in Institutional Reform Litigation, 78 Colum. L. REv. 784 (1978). For scholarly discussions of the dynamics of structural injunctions, see O. Fiss, Crvil Rights Injunctions 8-37 (1978); Diver, Judge as Political Powerbroker: Superintending Structural Change in Political Institutions, $65 V_{A}$. L. REv. 43, 52-53, 82-86 (1979).

124. Where the suit involves public universities, legislative action can supplement judicial action. Relief sought in a suit against Berkeley, for example, will be affected by Assembly Concurrent Resolution 70, adopted by the California legislature in September 1987, which called for each U.C. campus to: describe its exact admissions policies in its catalogues, create an advisory committee of community members, and ensure multi-ethnic representation on the academic senate committees governing admissions. Aoki, supra note 102 , at 261 . The California legislature has no direct control over the U.C. system. CAI. Const. art. IX, § 9. However, in adopting California Senate Resolution No. 2126 on March 24, 1988, the legislature exercised its oversight and budgetary powers to create a special committee to investigate Asian admissions at Berkeley and U.C. admissions in general. The senate committee's findings are likely to influence any judicial proceedings involving Berkeley.

125. The conflict will be more effectively resolved in the long run if defendant university participates in drafting the order and shaping the remedies. Parties in Lau v. Nichols jointly appointed a 
ages may also be appropriate. ${ }^{126}$ The following recommendations set forth possible elements of an injunction, to be modified as information concerning the admissions process becomes available through discovery.

A major impediment to increasing Asian American admissions appears to be the use of historic benchmarks. ${ }^{127}$ An injunction could require a university to discontinue the use of benchmarks that serve as upper limit quotas $^{\mathbf{1 2 8}}$ on candidates from rapidly increasing applicant pools.

The creation of an Asian recruitment coordinator position ${ }^{\mathbf{1 2 9}}$ could reduce the hurdles faced by Asian applicants in the advocacy admissions process $^{130}$ used by some highly selective universities. The Asian recruitment coordinator could be assigned to a region of the country with a large number of Asian candidates and also play an informal role in educating fellow admissions officers in the difficult process of overcoming stereotypes. In addition, as the implications of cross-cultural differences, ${ }^{131}$ and their effects on the admissions process, are evaluated at trial, a plaintiff

task force comprised of school board members, minority community leaders, and educators to study implementation plans. The San Francisco School Board, defendants in Lau, provided funding to hire experts and design future bilingual education programs in compliance with Title VI regulations. Lau v. Nichols, No. $72-6520$ (N.D. Cal. May 1974) (consent decree).

126. Damages are available in a suit based on the equal protection clause or Title VI itself. However, the Supreme Court has not conclusively determined the nature of the relief available in a suit based on Title VI regulations. In Guardians, four Justices agreed that both compensatory and prospective relief would be available for intentional and unintentional discrimination. Guardians Ass'n. v. Civil Serv. Comm'n, 463 U.S. 582, 635-39 (1983) (Stevens, J., joined by Brennan and Blackmun, JJ., dissenting); id. at 625-34 (Marshall, J., dissenting). Justice White, joined by Justice Rehnquist, asserted that compensatory or "make whole" remedies would not be appropriate without a showing of discriminatory intent. Id. at 596 (opinion of White, J.). The crucial vote, Justice O'Connor, disagreed with "the limitations that Justice White's opinion would place on the scope of equitable relief available to private litigants suing under Title VI," but since she concluded that Title VI required proof of intentional discrimination, she did not discuss the availability of monetary relief. Id. at $612 \&$ n.1 (O'Connor, J., concurring). Three circuits have suggested, when discussing $\$ 504$ of the Rehabilitation Act, thit only prospective relief is available in a suit filed under Title VI regulations. See Manecke v. School Bd., 762 F.2d 912, 922 n.8 (11th Cir. 1985) ("at least five Justices would not allow compensatory relief to a private plaintiff under Title VI absent proof of discriminatory intent") (emphasis in original); Marvin H. v. Austin Indep. School Dist., 714 F.2d 1348, 1357 (5th Cir. 1983) (no damages available absent intentional discrimination); Timms v. Metropolitan School Dist., 722 F.2d 1310, 1318 n.4 (7th Cir. 1983) (Title VI "has been held not to require proof of intentional discrimination except as a basis for compensatory relief"). For a Title VI case, see Craft v. Board of Trustees, 793 F.2d 140, 142, cert. denied, 107 S. Ct. 110 (1986) ("compensatory relief under section $2000 \mathrm{~d}$ [of Title VI] requires proof of discriminatory intent").

127. See supra notes $69-72$ and accompanying text.

128. Benchmarks can be used for both positive and negative purposes. If the court finds at trial that benchmarks have been used to impose a quota or ceiling on Asians, such uses should be eliminated, but progressive uses may still be permitted.

129. This remedy may only be appropriate at universities with a higher than threshold percentage of Asian applicants, a figure to be determined by the court. The Asian recruitment coordinator position should be filled by someone with an understanding of Asian cultural norms and familial backgrounds.

130. "For each candidate, an 'advocate' on the committee present[s] the case for acceptance," and the committee's perception of the applicant is strongly shaped by the force of that presentation. $R$. KLitgaARD, supra note 75 , at 30 .

131. For a summary of studies on cultural differences, see Sue \& Sue, Cultural Factors in the Clinical Assessment of Asian Americans, 55 J. Consulting \& Clinical. Psychology 479, 481-82 (1987); Sue, Ino \& Sue, Nonassertiveness of Asian Americans: An Inaccurate Assumption?, $30 \mathrm{~J}$. Counseling Psychology 581, 586 (1983). 
could consider methods to ameliorate the disparate impact of personal ratings on Asian American applicants. She could seek to modify the use of interviews, personal essays, and recommendation letters.

Furthermore, the university should be required to articulate in its application materials the criteria, specifically the subjective considerations, which serve as the basis for admissions decisions. ${ }^{132} \mathrm{~A}$ task force consisting of admissions officers, university administrators, community leaders, educators, and psychologists could work together to formulate the most suitable admissions standards, and the most effective means to articulate such standards, given the relevant educational objectives. The university also should be required to submit annual reports ${ }^{133}$ to the court and to the plaintiff's attorney documenting the admit rates for Asian Americans compared to Caucasians. A reporting requirement would push a university to be vigilant in its efforts to eliminate discriminatory barriers for Asian applicants and would also provide an external monitoring mechanism. ${ }^{134}$

While such policy changes may not ensure high Asian admit rates, they can serve to eliminate discriminatory and arbitrary barriers to highly selective universities for all applicants.

\section{CoNCLUSION}

This Note has provided a framework for examining the allegations of an upper limit quota on Asian American admissions. The four sample universities have illustrated the type of evidence necessary to challenge the admissions process and the legal theories upon which to plead a complaint. A suit can be brought against a public institution based on either the equal protection clause or Title VI, but such a suit would require evidence of discriminatory intent and would encounter difficult proof problems. A more promising approach is to challenge either a public or a private university on the basis of Title VI regulations, incorporating a disparate impact standard. If an Asian plaintiff is successful, a court order could mandate changes in specific admissions practices and require universities to articulate their subjective criteria for determining admissions.

The Asian admissions issue raises complex questions which may be unresolvable, but ultimately, it calls for an affirmation of the principles of racial equality fundamental to the promise of America.

132. For a discussion of the need for ascertainable standards in admissions, see Gellhorn \& Hornby, Constitutional Limitations on Admissions Procedures and Standards-Beyond Affirmativ'e Action, 60 VA. L. REv. 975, 1002-06 (1974).

133. Compliance reports are a common requirement in institutional reform litigation. See Special Project, supra note 123, at 824.

134. Such requirements would be similar to those instituted on remand by the district court. which required the Lau school board to submit to the court and to plaintiffs' attorney an annual publication describing its progress in providing bilingual education to San Francisco area school $\mathrm{c}$ ! ! dren. Lau v. Nichols, No. $72-6520$ (N.D. Cal. May 1974) (consent decree). 